\title{
The Relationship between Language Learning Strategies and Gender among Primary School Students
}

\author{
Manprit Kaur \\ Universiti Kebangsaan Malaysia, Malaysia \\ Email: manprit@streamyx.com \\ Mohamed Amin Embi \\ Universiti Kebangsaan Malaysia, Malaysia
}

\begin{abstract}
Research on language learning strategies has been carried out extensively since mid 1990s in Malaysia. These studies have covered the language learning strategies among secondary and undergraduate students but not on primary school students. The main objective of the study was to identify and compare the language learning strategies used by male and female primary school students. Data was collected using a survey questionnaire with 60 students from two classes of primary 6 , consisting of 30 male students and 30 female students. The instruments used in this study include a background information questionnaire and a bilingual Language Strategy Use Questionnaire adapted from Language Strategy Use Inventory by Cohen, Oxford and Chi (2002). Data was analyzed through mean, frequency and t-test. The findings revealed that there was a significant difference in the overall use of strategies between male and female students $(p=0.01)$. Female students tend to use overall language learning strategies more often than male students in learning English language. The pedagogical implications and suggestions for future research are further discussed.
\end{abstract}

Index Terms - language learning strategies, gender, primary school students, ESL

\section{INTRODUCTION}

The Malaysian Ministry of Education has set English language as a compulsory subject in all primary and secondary schools. English, particularly in primary education, aims at providing students with the essential English language skills namely listening, speaking, reading and writing, and knowledge of grammar to enable them to communicate (orally and in writing) in and out of school for different purposes and in different situations (KPM 1995).

Over the years, the standard of English has declined in Malaysian schools. Therefore, measures should be taken to raise the standard of English proficiency in schools. Studies designed to investigate language learning strategies employed by school students learning English in the Malaysian context play a significant role since the understanding of what students do in the language learning process and how it affects language success is important to assist students in learning the English language (Mohamed Amin 2000).

The term language learning strategy has been commonly used by a number of researchers. Wenden and Rubin (1987) defined learning strategies as steps, plans and routines used by the learner to facilitate the obtaining, storage, retrieval, and use of information. Richards and Platt (1992) stated that language learning strategies are intentional behavior and thoughts used by learners during learning to better help them understand, learn, or remember new information.

Language learning strategies is an extremely powerful learning tool according to O'Malley, Chamot, StewnerManzanares, Kupper, and Russo (1985). More than a quarter century ago, researchers such as Rubin (1975) and Stern (1975) explored the possibility that success in language learning might be related to how learners approach a task. Other researchers such as Cohen (1998) and Chamot (2001) have suggested that learners might be able to learn a language more effectively by the use of language learning strategies. Politzer and McGroarty (1985) and Wong-Fillmore (1985) agreed that the use of language learning strategy is positively associated with language acquisition.

\section{Statement OF THE PROBLEM}

There has been concern among politician, academician and parents with regards to the declining standard of English proficiency among students at all levels of education in Malaysia. Therefore there is a need for research to be carried out in the language learning field as language learning strategies influence the language learning process on the whole.

Local researchers who have shown interest to do research in the language learning field include; Mohamed Amin (1996); Radha Nambiar (1996) ; Faizahani (2002); Lau Ai Ting (2006) and Yoong (2010). Mohamed Amin (1996) identified language learning strategies among secondary school students; Radha Nambiar (1996) investigated language learning strategies of six first year undergraduate students when performing language activity; Faizahani (2002), Lau Ai 
Ting (2006) and Yoong (2010) examined language learning strategies employed by successful and less successful students in secondary schools. These studies address learning strategies among secondary and under graduate students in Malaysia. These studies have not covered the language learning strategies among primary school students. Primary school students differ from secondary and undergraduate students psychologically and socially as well as their approach to language learning.

\section{RESEARCH OBJECTIVES}

The research objectives of this study are to identify language learning strategies used most frequently by male and female students as well as to examine if there a significant difference in the overall strategies used by primary school students in terms of gender.

\section{METHODOLOGY}

A total of 60 respondents from two classes of primary 6, consisting of 30 male students and 30 female students were chosen as the samples for this study. The age of the respondents in the study ranged from 11 to 12 years old. These respondents have been exposed to target language for six years in this school learning English as a Second Language (ESL)

The instruments used in this study include a background information questionnaire and a bilingual Language Strategy Use Questionnaire adapted from Language Strategy Use Inventory by Cohen, Oxford and Chi (2002). The bilingual version of Language Strategy Use survey has been developed by Yoong Li Kuen (2010) and later translated by the experts in Malaysian National Translation Institut.

The actual questionnaire, Language Use Inventory by Cohen, Oxford and Chi (2002) comprises of 90 questions. These questions were categorized according to six language skills namely listening strategy, vocabulary strategy, speaking strategy, reading strategy, writing strategy and translation strategy.

The adapted version of Language Strategy Use Questionnaire consists of 40 bilingual statements concerning the four major English language skills, namely listening, speaking, reading and writing. There are ten statements for each language skill. This instrument has a strong reliability level as the Cronbach alpha coefficient is .91 (Yoong 2010). A 5point Likert scale ranging from 1 to 5 is used in this questionnaire. Students are required to mark each strategy according to the frequency of the strategy used to help them master English language. The 5-point Likert scale includes :1= Never true of me, 2=Usually not true of me, 3=Sometimes true of me, 4=Usually true of me and 5=Always true of me.

To determine the frequency of language learning strategies used, an interpretation mean score was employed. Students' responses were categorized into three categories, which is high, moderate and low frequency use of language strategy. Table 1.0 shows the frequency ratings for strategy use. These ratings were adapted from Oxford (1990).

TABLE 1.0

FREQUENCY RATINGS FOR STRATEGY USE

\begin{tabular}{lll}
\hline Frequency of use & Responses & Mean scores \\
\hline High & Always true of me & $4.5-5.0$ \\
& Usually true of me & $3.5-4.4$ \\
Moderate/medium & Sometimes true of me & $2.5-3.4$ \\
Low & Usually not true of me & $1.5-2.4$ \\
& Never true of me & $1.0-1.4$ \\
\hline
\end{tabular}

Independent sample t-test using SPSS version 11.5 was performed to see the differences between students' use of language learning strategies and their gender (male and female) with a significant level set at $\mathrm{p}<.05$.

\section{FINDINGS}

Table 2.0 shows the overall language learning strategy use of students according to their gender. Male and female students in this school are high frequency users of the reading strategy. Female students' mean score of reading strategy is 3.754 while male students' mean score of reading is 3.513. The mean score for all the four skills of listening, speaking, reading and writing is higher for female students compared to male students. The overall strategies mean score for female students is slightly higher, 3.655 compared to male students with 3.411. This shows that female students are generally high frequency users of language learning strategy while male students are moderate strategy users. 
TABLE 2.0

LEVEL OF STRATEGY USE ACCORDING TO GENDER

\begin{tabular}{lllllll}
\hline \multirow{2}{*}{ Strategy } & Male & & Female & \\
\cline { 2 - 6 } & Mean & Frequency & Rank & Mean & Frequency & Rank \\
\hline Listening & 3.386 & Moderate & 3 & 3.600 & High & 3 \\
Speaking & 3.256 & Moderate & 4 & 3.606 & High & 1 \\
Reading & 3.513 & High & 1 & 3.753 & High & High \\
Writing & 3.490 & Moderate & 2 & 3.660 & High \\
\hline Overall strategy & 3.411 & Moderate & & 3.655 & \\
\hline
\end{tabular}

Table 3.0 shows the frequency and percentage of individual strategy use according to gender. Male students used 12 $(30 \%)$ individual strategy with high frequency and $28(70 \%)$ individual strategy with moderate frequency. Female students used $24(60 \%)$ individual strategy with high frequency and $16(40 \%)$ individual strategy with moderate frequency. There is no low frequency individual strategy use for male and female students. This shows that female students use learning strategies more frequently in their language acquisition compared to male students.

TABLE 3.0

NuMBER AND PERCENTAGE OF INDIVIDUAL STRATEGY USE ACCORDING TO GENDER

\begin{tabular}{|c|c|c|c|c|c|c|}
\hline $\begin{array}{l}\text { Independent } \\
\text { variable }\end{array}$ & $\begin{array}{l}\text { High Frequency } \\
\text { Strategy Use }\end{array}$ & $\%$ & $\begin{array}{l}\text { Moderate } \\
\text { Frequency } \\
\text { Strategy Use }\end{array}$ & $\%$ & $\begin{array}{l}\text { Low Frequency } \\
\text { Strategy Use }\end{array}$ & $\%$ \\
\hline Male & 12 & 30 & 28 & 70 & 0 & 0 \\
\hline
\end{tabular}

It is also interesting to note that both male and female primary six students are high frequency users of 10 items namely A6, A8, A9, C1, C5, C9, C10, D6, D7 and D9. Table 4.0 explains the items used frequently by male and female students. Only three skills namely listening, reading and speaking were reported as high frequency strategies. Speaking skill is less frequently used by students. Out of the 10 items shown below, reading strategy is used most frequently by male and female students in learning English.

TABLE 4.0

High FREQUENCY OF INDIVIDUAL STRATEGY USE BY MALE AND FEMALE STUDENTS

\begin{tabular}{lll}
\hline Item no. & Individual Strategy & Skills \\
\hline A6 & Listen for key words that seem to carry the bulk of the meaning & Listening \\
A8 & Ask speakers to repeat what they said if it wasn't clear to me & Listening \\
A9 & Ask for clarification if I do not understand it the first time around. & Listening \\
C1 & Read as much as possible in the target language & Reading \\
C5 & Read a story or dialogue several times until I understand it & Reading \\
C9 & Guess the approximate meaning by using clues from the context of the reading material. & Reading \\
C10 & Use a dictionary to get a detailed sense of what individual words mean & Reading \\
D6 & Review what I have already written before continuing to write more & Writing \\
D7 & Use reference materials such as a glossary, a dictionary, or a thesaurus to help find or verify & Writing \\
& words in the target language & Writing \\
D9 & Revise my writing once or twice to improve the language and content & \\
\hline
\end{tabular}

Table 5.0 displays the strategies used most frequently by male students. Reading and writing strategies are shown to be used most frequently while listening and speaking strategies are used less frequently by students. The mean scores for reading and writing are 3.513 and 3.490 respectively while the mean scores for listening and speaking are 3.386 and 3.256 .

TABLE 5.0

STRATEgIES USED Most FreQUently by MALE STUdents

\begin{tabular}{lcc} 
& STRATEGIES USED MOST FREQUENTLY BY MALE STUDENTS \\
\hline Strategy Use & Mean & Rank \\
\hline Listening & 3.386 & 3 \\
Speaking & 3.256 & 4 \\
Reading & 3.513 & 1 \\
Writing & 3.490 & 2 \\
\hline
\end{tabular}

Table 6.0 shows the strategies used most frequently and least frequently by female primary six students. Female students are fond of using the reading and writing strategy when learning English. The mean score for reading and writing is slightly higher than male students with 3.753 and 3.660 while the mean scores for speaking and listening are 3.606 and 3.600 .

TABLE 6.0

STRATEGIES USED Most FREQUENTLy By FEMALE STUdENTS

\begin{tabular}{lll}
\hline Strategy Use & Mean & Rank \\
\hline Listening & 3.600 & 4 \\
Speaking & 3.606 & 3 \\
Reading & 3.753 & 1 \\
Writing & 3.660 & 2 \\
\hline
\end{tabular}


As can be observed from Table 7.0, there is a significant difference in the overall strategies used by primary six students. An independent t-test was conducted to compare the overall language learning strategies use scores for male and female students. On the whole there is a significant difference in scores for male and female students in listening (p $=0.013)$, speaking $(p=0.000)$ and reading strategies $(p=0.032)$. However, writing strategy $(p=0.100)$ is not significantly different for male and female students.

The overall mean score for male students is 3.411 while the overall mean score for female students is 3.655 . The overall significant level is $0.001(\mathrm{p}<0.05)$. This shows that female students use more strategies than male students in acquiring English language. Therefore, this finding corresponds to Oxford's (1990) assertion that gender is a factor that affects the strategy use in language learning.

TABLE 7.0

VARIATION OF STRATEGY CATEGORY USE BASED ON GENDER

\begin{tabular}{|c|c|c|c|c|c|c|}
\hline \multirow[t]{2}{*}{ Strategy Use } & \multicolumn{2}{|l|}{ Male } & \multicolumn{4}{|c|}{ Female } \\
\hline & Mean & SD & Mean & SD & $\begin{array}{l}\text { Significant } \\
\text { level }\end{array}$ & $\begin{array}{l}\text { Pattern of } \\
\text { Variation }\end{array}$ \\
\hline Listening & 3.386 & 0.2542 & 3.600 & 0.3787 & 0.013 & $\mathrm{~F}>\mathrm{M}$ \\
\hline Speaking & 3.256 & 0.3616 & 3.606 & 0.3647 & 0.000 & $\mathrm{~F}>\mathrm{M}$ \\
\hline Reading & 3.513 & 0.4407 & 3.753 & 0.4057 & 0.032 & $\mathrm{~F}>\mathrm{M}$ \\
\hline
\end{tabular}

\section{DISCUSSION AND CONCLUSION}

Reading ( $\mathrm{M}=3.513)$ and writing $(\mathrm{M}=3.490)$ strategies are shown to be used most frequently while listening ( $\mathrm{M}$ =3.386) and speaking $(\mathrm{M}=3.256)$ strategies are used less frequently by male students. In learning the target language, the high frequency strategies used by male students consist of four listening strategy, five reading strategy and three writing strategy. The most frequently used strategy by male students was item C10: Use a dictionary to get a detailed sense of what individual words mean (reading strategy; $M=4.53$ ).

Male students are not high frequency users of the speaking strategy. This could be due to their lack of vocabulary and self confidence. Furthermore, students learn English language only in the classroom setting most of the time and they do not practice the language out of their classrooms, so, it is reasonable they use speaking strategy least frequently.

Reading $(M=3.753)$ and writing $(M=3.660)$ strategies are shown to be used most frequently while speaking ( $M$ =3.606) and listening $(\mathrm{M}=3.600)$ strategies are used less frequently by female students. The high frequency strategies used by female students consist of four listening strategy, six speaking strategy, eight reading strategy and five writing strategy.

The most frequently used strategy by female students was item C10: Use a dictionary to get a detailed sense of what individual words mean (reading strategy; $M=4.70$ ). This finding demonstrates that primary school students are generally dependent on their teachers in their language acquisition.

To examine the differences in the use of language learning strategies between male and female students, $\mathrm{t}$-test was used. Based on the t-test results, there was a significant difference in the overall use of strategies between male and female students $(p=0.01)$. According to the total mean of male $(M=3.411)$ and female $(M=3.655)$ students, it could be concluded that female students use learning strategies more often than male students. This result is consistent with Mohamed Amin (2000), Kamarul Shukri et al (2009) and Green and Oxford's (1995) findings.

Gender differences in the classrooms might be related to biological and socialization factors (Green \& Oxford 1995). Oxford (1989) asserted that females generally have greater social orientation, stronger verbal skills and greater conformity to linguistics and academic norms compared to males. Mohamed Amin (2000) posits that female students are generally more matured than male students therefore they perform better in their studies.

Zhou (2010) revealed that female students are more active in using language learning strategies and more motivated to do well in schools compared to male students. Female primary school students are also willing to work hard and use learning strategies to improve their learning while male students are more indulged in playing.

When examining the four categories of strategies, female students reported a greater use of listening strategies $(\mathrm{p}=$ $0.013)$, speaking strategies $(p=0.000)$ and reading strategies $(p=0.032)$. However, there was no significant differences shown in writing strategies $(\mathrm{p}=0.100)$. Writing strategy does not show a significance difference due to primary school teachers' frequent emphasize on writing skills Overall, both genders used three similar strategies in enhancing their writing skills (item D6, D7 and D9).

The findings of this study indicate that female students use more strategies than male students in learning a language. Since language strategy use is closely related to students' performance (O'Malley \& Chamot 1990), teachers should ensure that all primary school students, male and female, realize the importance of using language learning strategies in their learning. 


\section{REFERENCES}

[1] Chamot, A.U.( 2001). The role of learning strategies in second language acquisition. In M.P. Breen (Ed.), Learner contributions to language learning: New directions in research (pp. 25-43). Harlow, England: Longman.

[2] Cohen, A. D. (1998). Strategies in learning and using a second language. Harlow, Essex: Longman.

[3] Cohen, A. D., Oxford, R. L., \& Chi, J. C. (2002). Language Strategy Use Survey. Minneapolis, MN: Center for Advanced Research on Language Acquisition, University of Minnesota.

[4] Faizahani Ab. Rahman. (2002). Strategies Employed by Good and Weak English Learners and Factors Affecting the Choice of Strategies. Unpublished Master's Thesis. Faculty of Education, Universiti Kebangsaan Malaysia.

[5] Green, J., \& Oxford, R. (1995). A Closer Look at Learning Strategies, Second Language Proficiency, and Gender. TESOL Quarterly, 29, p.261- 297.

[6] Kamarul Shukri, Mohamed Amin, Nik Mohd Rahimi and Zamri Mahamod. (2009). A Closer Look at Gender and Arabic Language Learning Strategies Use. European Journal of Social Sciences, Volume 9, Number 3, p 399-407.

[7] Kementerian Pendidikan Malaysia. (1995). Sukatan Pelajaran Sekolah Rendah Bahasa Inggeris. Kuala Lumpur: Dewan Bahasa dan Pustaka.

[8] Mohamed Amin Embi. (1996). Language Learning Strategies Employed by Secondary School Students Learning English as a Foreign Language in Malaysia. Unpublished Doctoral Dissertation. School of Education, University of Leeds.

[9] Mohamed Amin Embi. (2000). Language Learning Strategies: A Malaysian Context. Bangi: Faculty of Education, UKM.

[10] Lau, Ai Ting. (2006). A Case Study of the Language Learning Strategies of Successful and Less Successful ESL Learners in a Suburban in Sibu, Sarawak. Unpublished Master's Thesis. Faculty of Education, Universiti Teknologi Malaysia.

[11] O'Malley, J. M, Chamot, A.U., Stewner-M., Rocco P., and L. Kupper. (1985). Learning Strategy Applications with Students of English as a Second Language in TESOL Quarterly 19: 557-584.

[12] Oxford, R. L. and Nyikos, M. (1989). Variables affecting choice of language learning strategies by university students, The Modern Language Journal, 73 (3): 291-300.

[13] Oxford, R. L. (1990). Language learning strategies: What Every Teacher Should Know. New York: Newbury House/Harper and Row.

[14] Politzer, R.L. and McGroaty, M. (1985). An exploratory study of learning behaviors and their relationship to gains in linguistic and communicative competence. TESOL Quarterly 19, pp. 103-124.

[15] Radha Nambiar. (1996). Language Learning Strategies Of Six Malaysian ESL Learners When Performing Selected Language Activities. Masters theses. Faculty of Language Studies. Universiti Kebangsaan Malaysia.

[16] Richards, J. and Platt J. (1992). Longman Dictionary of Language Teaching and Applied Linguistics. Essex: Longman.

[17] Rubin, J. (1975). What the "Good Language Learner" can Teach Us. TESOL Quarterly, 9, 41-51.

[18] Stern, H. H. (1975). What can We Learn from Good Language Learners? Canadian Modern Language Review, 31, $304-318$.

[19] Wenden, A. and Rubin, J. (1987). Learner strategies in language learning. New York: Prentice Hall.

[20] Wong Fillmore, L. (1985). When Does Teacher Talk Work as Input? S. Gass and C. Madden, Eds. Input in Second Language Acquisition. Rowley, MA: Newbury House.

[21] Yoong L.K. (2010). English Language Learning Strategies used by Form Six Students in Secondary Schools. UKM Masters Thesis.

[22] Zhou Y. (2010). English Language Learning Strategy Use by Chinese Senior High School Students. English Language Teaching. Vol. 3, Iss. 4; pg. 152-158

Manprit Kaur is currently an English school teacher. She obtained her Masters in TESL from the National University of Malaysia in 2011 and Bachelors from the Technology University of Malaysia in 2001.

Mohamed Amin Embi is a Professor of language education at the Faculty of Education, Universiti Kebangsaan Malaysia. He has published more than 200 articles, 20 books and 40 chapters in book on the area of language learning strategies and e-learning. 